\title{
Serum bone Gla protein and carboxyterminal cross-linked telopeptide of type I collagen in patients with Cushing's syndrome
}

\author{
A Sartorio, A Conti, S Ferrario, E Passini, T Re, B Ambrosi
}

\section{Summary}

Serum bone Gla protein, a marker of bone formation, and carboxyterminal crosslinked telopeptide of type I collagen levels, an index of bone resorption, were evaluated in eight patients with active Cushing's syndrome and in four with 'preclinical' Cushing's syndrome, before and after surgery. In basal conditions, serum bone Gla protein levels were significantly lower $(p<0.0001)$ in patients with active Cushing's syndrome $(1.0 \pm 0.35 \mathrm{ng} / \mathrm{ml})$ than in controls $(5.4 \pm 0.15 \mathrm{ng} / \mathrm{ml})$; two out of four patients with the 'preclinical' form had reduced bone Gla protein levels, while in the other two cases levels were in the normal range. Serum levels of carboxyterminal crosslinked telopeptide of type I collagen $(3.0 \pm 0.4 \mathrm{ng} / \mathrm{ml})$, although slightly reduced, were similar to those recorded in controls (4.1 $\pm 0.3 \mathrm{ng} \mathrm{ml})$, both in patients with active and with preclinical Cushing's syndrome. After surgery serum levels of both marker proteins significantly increased in seven out of eight patients with active Cushing's syndrome; in one patient, who was not cured after surgery, bone Gla proteins levels remained lower than in normals, while levels of carboxyterminal cross-linked telopeptide of type I collagen had a transient increase after six months. In the two patients with a 'preclinical' Cushing's syndrome who underwent surgery, a significant rise of the levels of both marker proteins was observed, similar to that observed in patients with active Cushing's syndrome. It was concluded that serial determinations of these new markers of bone formation and resorption may be usefully employed to follow-up the clinical course of Cushing's syndrome and provide information on the rate of bone turnover in response to medical and/or surgical therapies. Moreover, the evaluation of these markers in preclinical states of Cushing's syndrome might suggest the need for surgery.

Keywords: bone turnover, Cushing's sydrome

After the first historical report, ${ }^{1}$ many studies confirmed the presence of a steroid-induced negative effect on bone. ${ }^{2-7}$ In this respect, the chronic maintenance of supraphysiological levels of glucocorticoids, of endogenous and exogenous origin, is commonly associated with the development of severe osteopenia in man. ${ }^{5,6}$ The mechanisms by which glucocorticoids produce their effects on bone are to date only partially understood ${ }^{2,6,8}$; histological studies of bone in patients with steroid-induced osteopenia have demonstrated both decreased formation rates and increased numbers of osteoclasts and resorption sites. ${ }^{9-11}$

Up to now, the effects of glucocorticoids on bone have mainly been studied in patients receiving exogenous steroids, ${ }^{5,6,12-14}$ while few data are available on steroid-induced damage in patients with Cushing's syndrome. In these patients, the radiographic evidence of reduced bone mass and pathologic fractures have been described, ${ }^{4,15}$ while the evaluation of bone formation and resorption activities has been partially prevented by the lack of reliable and specific biochemical markers, able to detect the less evident modifications of bone turnover. ${ }^{16-18}$

We therefore determined serum bone Gla protein, a marker of bone formation, and carboxyterminal cross-linked telopeptide of type I collagen (ICTP), an index of bone resorption, in a group of patients with Cushing's syndrome, before and after surgery. Moreover, although the natural history of glucocorticoid-induced bone loss is not yet fully characterized, it has been reported that osteopenia and fractures might occur prior to the onset of other manifestations of Cushing's syndrome, suggesting that severe bone loss may occur early in the course of increased endogenous glucocorticoid exposure.,19 Therefore, the modifications of these markers were evaluated, also in some patients with socalled 'preclinical' Cushing's syndrome, a condition that is increasingly recognised thanks to the wide availability of new imaging techniques detecting adrenal incidentalomas. ${ }^{20}$

\section{Materials and methods}

Eight patients with active Cushing's syndrome (one man, age range 22-46 years, cases $1-8$ ) and four with 'preclinical' Cushing's syndrome (three men, age range: $42-74$ years, cases 912) were admitted to the study. The main clinical features and baseline hormonal data of the patients are shown in table 1 .

The diagnosis of Cushing's syndrome was made on the basis of clinical, hormonal and
Milan, Italy

Accepted 12 December 1995 
Table 1 Clinical features and baseline hormonal data of patients with Cushing's syndrome

\begin{tabular}{lllllll}
\hline Case & Diagnosis & Sex & Age (yr) & $\begin{array}{l}\text { Cortisol } \\
\text { (nmol/l) }\end{array}$ & $\begin{array}{l}\text { Adreno- } \\
\text { corticotropin } \\
\text { (pmol/l) }\end{array}$ & $\begin{array}{l}\text { Urinary free } \\
\text { cortisol } \\
\text { (nmol/day) }\end{array}$ \\
\hline 1 & CD & F & 46 & 830 & 7.0 & 719 \\
2 & CD & F & 22 & 469 & 13.0 & 643 \\
3 & CD & M & 28 & 762 & 20.0 & 555 \\
4 & CD & F & 25 & 957 & 14.1 & 767 \\
5 & CD & F & 33 & 1217 & 11.0 & 1475 \\
6 & CD & F & 38 & 1034 & 17.4 & 316 \\
7 & AA & F & 28 & 1329 & 0.4 & 367 \\
8 & EAS & F & 31 & 883 & 20.7 & 630 \\
9 & PCC & F & 41 & 571 & 0.4 & 690 \\
10 & PCC & M & 66 & 625 & 0.7 & 311 \\
11 & PCC & M & 68 & 255 & 1.0 & 374 \\
12 & PCC & M & 74 & 589 & 0.7 & 434 \\
\hline
\end{tabular}

$\mathrm{CD}$, Cushing's disease; AA, adrenal adenoma; EAS, ectopic adrenocorticotropin secretion; PCC, preclinical Cushing's syndrome.

Control group (mean $\pm S E$ ): cortisol: $403 \pm 20 \mathrm{nmol} /$; adrenocorticotropin: $5.4 \pm 0.8$ $\mathrm{pmol} / \mathrm{l}$; urinary free cortisol: $120 \pm 8.8 \mathrm{nmol} /$ day

Table 2 Cortisol and adrenocorticotropin levels and urinary free cortisol excretion after surgery in patients with Cushing's syndrome

\begin{tabular}{lllcll}
\hline Case & Diagnosis & Therapy & $\begin{array}{l}\text { Cortisol } \\
\text { (nmolll) }\end{array}$ & $\begin{array}{l}\text { Adreno- } \\
\text { corticotropin } \\
\text { (pmoll) }\end{array}$ & $\begin{array}{l}\text { Urinary free } \\
\text { cortisol } \\
\text { (nmollday) }\end{array}$ \\
\hline 1 & CD & ADX (1) & 30 & 55.9 & $<10$ \\
2 & CD & PA & 122 & 2.6 & $<10$ \\
3 & CD & PA & 27 & $<0.2$ & 10 \\
4 & CD & PA & $<10$ & 7 & 59 \\
5 & CD & PA & 335 & 1.4 & 133 \\
6 & CD & PA & 426 & 5.1 & 427 \\
7 & AA & ADX (2) & 16 & 1.8 & 26 \\
8 & EAS & PL & 182 & 3.7 & 55 \\
9 & PCC & ADX & $<10$ & 0.4 & $<10$ \\
10 & PCC & ADX & 298 & 11.2 & 47 \\
\hline
\end{tabular}

CD, Cushing's disease; AA, adrenal adenoma; EAS, ectopic adrenocorticotropin secretion; PCC, preclinical Cushing's syndrome; $\mathrm{ADX}$, adrenalectomy (1, bilateral; 2 , unilateral); PL, pulmonary lobectomy; PA, pituitary adenomectomy.

Control group (mean $\pm \mathrm{SE}$ ): cortisol: $403 \pm 20 \mathrm{nmol} /$; adrenocorticotropin $5.4 \pm 0.8$ $\mathrm{pmol} / \mathrm{l}$; urinary free cortisol: $120.2 \pm 8.8 \mathrm{nmol} /$ day

radiological findings. The 'preclinical' condition was defined by the presence of an incidentally detected adrenal mass in patients without any evident sign or symptom suggestive of hypercortisolism, who showed normal baseline serum cortisol, high urinary free cortisol excretion, suppressed levels of plasma adrenocorticotropin, cortisol levels not adequately suppressed by overnight dexamethasone and high-dose dexamethasone tests, and absent or impaired responses to corticotropinreleasing hormone stimulation.

Ten patients (cases 1-10) were studied before and after surgery; six patients underwent transsphenoidal adenomectomy (cases 2-6), four adrenalectomy (cases 1, 7, 9, 10), one pulmonary lobectomy for removal of a bronchial carcinoid (case 8). Nine out of ten patients showed a remission of the disease, while case 6 was not cured, as shown in table 2 . All operated patients, except cases 5, 6 and 10, became hypoadrenal and were on cortisone acetate $(25-37.5 \mathrm{mg} /$ day $)$ replacement therapy for six (case 4) and 12 months (cases 1-3,
7-9) respectively. None of the patients had any other disease or took drugs known to affect bone mineral metabolism during the follow-up period.

Data obtained from patients were compared 0 with those recorded in an age- and sex- on matched control group ( $n=50$, ages 25-69 years), recruited among friends and colleagues.

\section{RADIOIMMUNOASSAY}

Serum bone Gla protein, ICTP and cortisol levels and plasma adrenocorticotropin levels $\stackrel{\vec{\rho}}{\mathrm{S}}$ were determined by commercial radioimmu- $\bar{O}$ noassay and IRMA kits (CIS Diagnostici, Italy; 을 Orion Diagnostica, Finland; Diagnostic Pro- $\frac{\bar{m}}{7}$ ducts, USA and Nichols Institute, USA, $\stackrel{\mathbb{Q}}{\unrhd}$ respectively). Urinary free cortisol levels were ڤ determined by radioimmunoassay (Diagnostic Product, USA). The intra- and inter-assay coefficients of variation were $4.5-6.2 \%$ (bone $\vec{\omega}$ Gla protein), 5.0-6.8\% (ICTP), 4.6-5.4 (cortisol) and 3.1-7.3\% (adrenocorticotropin). The lower limits of sensitivity were $0.5 \mathrm{ng} \mathrm{ml}$ (bone Gla protein), $0.5 \mathrm{ng} / \mathrm{ml} \mathrm{N}$ (ICTP), $11.0 \mathrm{nmol} / 1$ (serum cortisol), 5.4 品 $\mathrm{nmol} /$ day (urinary free cortisol) and $0.44 \mathrm{pmol} / 1$ (adrenocorticotropin).

\section{STATISTICAL ANALYSIS}

All data are expressed as mean \pm standard $\vec{c}$ error. Student's paired and unpaired $t$ test were calculated as appropriate; p-values less $\vec{\theta}$ than 0.05 were considered significant

\section{Results}

At baseline, serum bone Gla protein levels were significantly lower $(p<0.0001)$ in pa- $\mathbb{D}$ tients with active Cushing's syndrome $\vec{F}$ $(1.0 \pm 0.35 \mathrm{ng} / \mathrm{ml})$ than in controls $(5.4 \pm$ ) $0.15 \mathrm{ng} / \mathrm{ml}$ ); no significant differences in bone Gla protein levels were found in relation to the different aetiologies. Two out of four patients with the 'preclinical' condition (cases 9 and 10) had reduced bone Gla protein levels $(0.4$ and $0.2 \mathrm{ng} / \mathrm{ml}$, respectively), while in the other two cases (cases 11 and 12) bone Gla protein levels were in the normal range $(4.5$ and $4.6 \mathrm{ng} / \mathrm{ml}$, respectively).

Mean ICTP levels $(3.0 \pm 0.4 \mathrm{ng} / \mathrm{ml})$, although slightly reduced, were similar to those recorded in controls $(4.1 \pm 0.3 \mathrm{ng} / \mathrm{ml})$, both in $N$ patients with active $(3.3 \pm 0.6 \mathrm{ng} / \mathrm{ml})$ and in $N$ those with the preclinical Cushing's syndrome $N$ $(2.3 \pm 0.05 \mathrm{ng} / \mathrm{ml})$; no significant differences in ICTP levels were found in relation to the different aetiologies.

No significant correlations were found be- $\stackrel{\mathscr{D}}{\rightarrow}$ tween baseline bone Gla protein or ICTP levels and cortisol levels.

After surgery, serum bone Gla protein and ICTP levels significantly increased in seven out $\stackrel{\mathbb{Q}}{\&}$ of eight patients with active Cushing's syndrome, as shown in figure 1 ; in patient 6 , who 8 was not cured by surgery, bone Gla protein levels remained lower than in normals, while ICTP levels had a transient increase after six months. In the two patients with 'preclinical' Cushing's syndrome (cases 9 and 10) who underwent surgery, the diagnosis of benign 
Figure 1 Serum bone Gla protein levels in eight patients with active Cushing's syndrome $(O)$ and in two patients with 'preclinical' Cushing's syndrome $(\triangle) ; 0$, not cured patient (case no 6 )

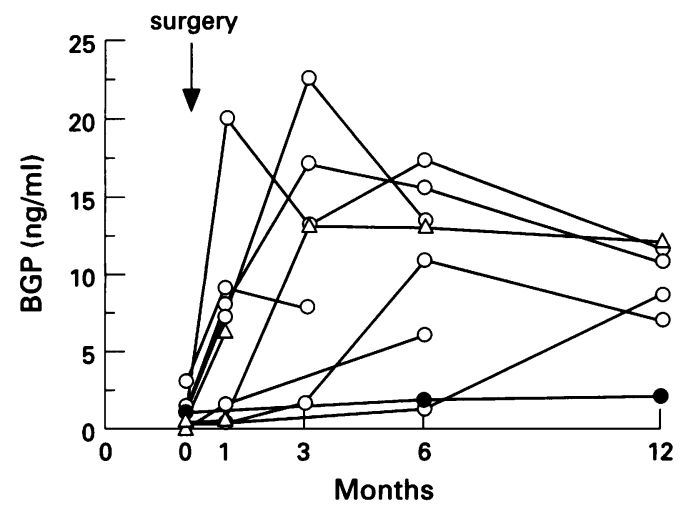

Figure 2 Serum ICTP levels in eight patients with active Cushing's syndrome $(O)$ and in two patients with 'preclinical' Cushing's syndrome $(\triangle)$; , not cured patient (case no 6)

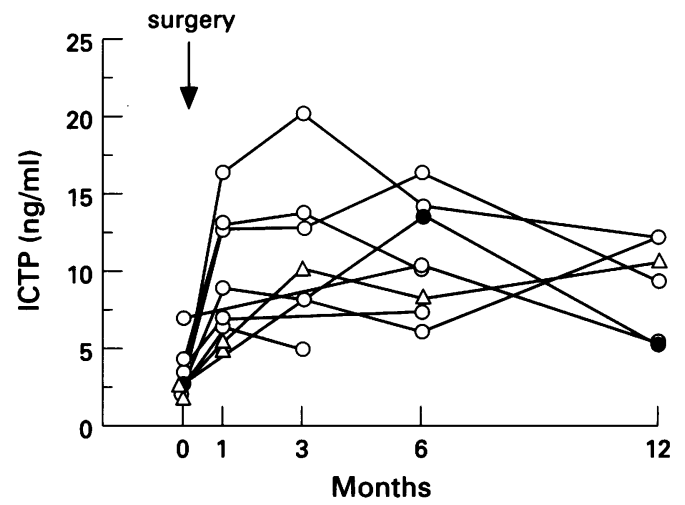

cortical adenoma was confirmed by histology. A significant rise of bone Gla protein and ICTP levels was observed, similar to those observed in patients with active Cushing's syndrome (figures 1 and 2).

No significant correlations were found between bone Gla protein or ICTP levels and cortisol levels six months after surgery.

\section{Discussion}

Although the steroid-induced effects on bone are well described in patients treated with high amounts of corticosteroids for long periods, ${ }^{5-6,12,13}$ few studies have extensively evaluated bone turnover in patients with endogenous Cushing's sydrome, probably due to its low prevalence. Reduced bone mass has been described in these patients, ${ }^{4,15,21}$ while the exact mechanisms involved in the appearance of bone disease and the modifications of bone turnover which occur after cure of the disease are not entirely clear. ${ }^{13}$

Preliminary studies in active Cushing's syndrome have shown the presence of reduced bone Gla protein levels, which significantly increased six months after surgery in cured patients. ${ }^{22,23}$ Recently, these results have been confirmed by Piovesan $e t a l,{ }^{24}$ who reported the inhibitory effects of steroid excess on osteoblastic activity and also on soft tissue collagen synthesis, as documented by the finding of reduced levels of the aminoterminal propeptide of type III procollagen (PIINN).

To our knowledge, few data are available on the steroid-induced effects on bone resorption in patients with endogenous Cushing's syn- drome. During treatment with glucocorticoids, a significant increase of bone resorption, associated with a suppression of bone formation, has been documented. ${ }^{25}$ However, it cannot be ruled out that these effects might be influenced, at least in part, by the primary disease.

In the present study, a reduction of bone Gla protein levels was found in all patients with Cushing's syndrome, thus confirming that osteoblastic activity is negatively affected by excess steroids. This finding is in line with the observations showing that supraphysiological concentrations of exogenous glucocorticoids suppress bone Gla protein levels, an effect which can occur within a few days of glucocorticoid therapy. ${ }^{13,26}$ As recently demonstrated in ewes, a valid model for the study of bone turnover, serum bone Gla protein levels appear to be a sensitive index of the inhibitory effect of corticoids on osteoblasts. ${ }^{27}$

Serum ICTP levels, which are a reliable index of bone resorption, ${ }^{16}$ were similar to those reported in control subjects; this finding might be explained by the fact that the increase of bone resorption activity usually occurs only after prolonged exposure to steroids, ${ }^{28}$ as already documented in patients treated with pharmacological doses. ${ }^{29}$ In endogenous Cushing's syndrome, the existence of normal resorption activity associated with low bone formation might contribute to the overall negative effect of hypercortisolism on bone turnover.

Our finding of low levels of bone Gla protein in two patients with preclinical Cushing's syndrome suggests that bone involvement may occur prior to the onset of other features of Cushing's syndrome. In these patients, changes in these markers of bone turnover need to be carefully monitored, as they reveal the appearance of other clinical and/or metabolic features induced by the hypercortisolism, which might require surgical treatment. In this respect, it is worth noting that the steroidinduced effects on bone formation and resorption activities disappear after successful surgery, suggesting that the bone damage may be partially reversed. These findings agree with those reported by Pocock et al,,$^{30}$ who found a significant increase in bone density (up to $20 \%$ ) of the lumbar spine in patients with cured Cushing's syndrome, and by Bressot et $a l, 9$ who observed increases in cancellous bone volume, osteoid surface, mineral appositional rate and bone formation rate after adrenalectomy. A similar rebound increase in boneforming activity also occurs following the discontinuation of chronic glucocorticoid therapy. ${ }^{30}$

It is of interest that bone Gla protein and ICTP levels increased to above the normal range after surgery in cured patients; this finding might be explained as a temporary hyperactivation of bone turnover following the removal of the inhibitory effects of glucocorticoids. On the other hand, the absence of an increase in bone $\mathrm{Gla}$ protein levels after surgery, suggesting the persistence of a steroid-induced negative effect on bone formation, 


\section{Summary points}

- in patients with 'active' Cushing's syndrome the existence of normal resorption activity associated with low bone formation might partly explain the overall negative effect of hypercortisolism on bone turnover

- the effects of excess steroid on bone formation promptly disappear after successful therapy

- bone involvement may occur prior to the onset of other features in patients with 'preclinical' Cushing's syndrome

- the evaluation of bone markers in 'preclinical' states of Cushing's syndrome might be a useful criterion for the consideration of a surgical approach

- serial determination of markers of bone formation and resorption may be employed to follow the clinical course of the syndrome might be used as an additional index of persistent disease. It is relevant that ICTP levels, despite a transitory increase six months after surgery, had decreased by 12 months after surgery, reverting back to baseline levels.

In conclusion, serial determinations of these ${ }^{0}$ new markers of bone formation and resorption $\stackrel{0}{0}$ may be employed to follow up the clinical course of Cushing's syndrome and give in- $\frac{2}{3}$ formation on the rate of bone turnover in $\stackrel{8}{\mathbb{2}}$ response to medical and/or surgical therapies. $c$. Moreover, their evaluation in preclinical states $\vec{F}$ of Cushing's syndrome might be useful criteria for the consideration of a surgical approach.

This work was partially supported by Progetti di Ricerca $\stackrel{0}{\overparen{D}}$ Corrente, Centro Auxologico Italiano, IRCCS, Milan, $\frac{2}{2}$
Italy.
1 Cushing $\mathrm{H}$. The basophil adenomas of the pituitary body and their clinical manifestations. Bull fohns Hopkins Hosp 1932; 50: 137 - 95 .

2 Kukreja SC, Bowser EN, Hargis GK, Henderson WJ, Williams GA. Mechanisms of glucocorticoid-induced osteopenia: role of parathyroid glands. Proc Soc Exp Biol Med 1976; 152: 358-61.

3 Burckhardt P. Corticosteroids and bone: a review. Horm Res 1984; 20: 59-64

4 Petersen P, Jacobsen SEH. Cushing's disease presenting Petersen P, Jacobsen SEH. Cushing's disease presenting
with severe osteoporosis. Acta Endocrinol (Copenh) 1986; with severe osteoporosis. Acta Endocrinol (Copenh) 1986; 111: $168-73$.

5 Reid IR. Pathogenesis and treatment of steroid osteoporosis. Clin Endocrinol 1989; 30: 83-103.

6 Lukert BP, Raisz LG. Glucocorticoid-induced osteoporosis: pathogenesis and management. Ann Intern Med 1990; 112: 352-64.

7 Gennari C. Glucocorticoid induced osteoporosis. Clin Endocrinol 1994; 41: $273-4$

8 Lukert BP, Adams JS. Calcium and phosphorus homeostasis in man: effect of corticosteroid. Arch Intern Med 1976; 136: $1249-53$.

9 Bressot C, Meunier PJ, Chapuy MC, Lejeune E, Edouard C, Darby AJ. Histomorphometric profile, pathophysiology and reversibility of corticosteroid-induced osteoporosis. and reversibility of corticosteroid-induced

10 Meunier PJ, Bressot C. Endocrine influences on bone cells and bone remodeling evaluated by clinical histomorphometry. In: Parsons JA ed. Endocrinology of calcium metabolism. New York: Raven Press, 1982; pp 445-65.

1 Meunier PJ, Dempster W, Edouard C, Chapuy MC, Arlot $\mathrm{M}$, Charhon S. Bone histomorphometry in corticosteroid induced osteoporosis in Cushing's syndrome. Adv Exp Med Biol 1984; 171: $191-200$.

12 Gluck OS, Murphy WA, Hahn TJ, Hahn B. Bone loss in adults receiving alternate day glucocorticoid therapy. adults receiving alternate day

13 Lukert BP, Higgins JC, Stoskopf MM. Serum osteocalcin is increased in patients with hyperthyroidism and decreased in increased in patients with hyperthyroidism and decreased in patients receiving g

14 Curtiss PH, Clark WS, Herndon $\mathrm{CH}$. Vertebral fractures resulting from prolonged cortisone and corticotrophin therapy. $¥ A M A$ 1954; 156: 467-9.

15 Howland WJ, Pugh DG, Sprague RG. Roentgenologic changes in the skeletal system in Cushing's syndrome. Radiology 1968; 71: 69-78.

16 Risteli L, Risteli J. Biochemical markers of bone metabolism. Ann Med 1993; 25: 385-93.

17 Sartorio A, Conti A, Monzani M. New markers of bone and collagen turnover in children and adults with growth hormone deficiency. Postgrad Med f 1993; 69: 846-50.
18 Sartorio A, Monzani M, Conti A, Casati G, Faglia G. Serum amino-terminal propeptide of type III procollagen (PIINP) levels in patients with acromegaly before and after $N$ pituitary adenomectomy. Eur f Intern Med 1993; 4: 79-83.

19 Cryer PE, Kissane JM. Vertebral compression fractures with accelerated bone turnover in a patient with Cushing's 6 disease (clinicopathologic conference). Am F Med 1980; 68: $932-40$

20 Ambrosi B, Peverelli S, Passini E, et al. Abnormalities of endocrine function in patients with clinically "silent" adrenal 음 endocrine function in patients with clinically "silent" adrenal $\supset$ mass. Eur 7 Endocrinol 1995; 132: 422-8.
Hough S, Teitelbaum SL, Bergfeld MA, Avioli LV. Isolated $\vec{C}$ skeletal involvement in Cushing's syndrome: response to skeletal involvement in Cushing's syndrome: resp

22 Sartorio A, Ambrosi B, Colombo P, Morabito F, Faglia G.

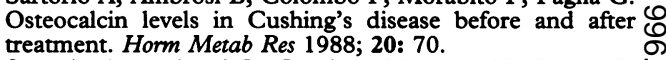

23 Sartorio A, Ambrosi B, Conti A, Monzani M, Faglia G. Modifications in bone-Gla protein (BGP) and aminoterminal propeptide of type III procollagen (PIINP) levels in one patient with Cushing's syndrome. Horm Metab Res 1991; 23: 247-9.

24 Piovesan A, Terzolo M, Reimondo G et al. Biochemical ֻ markers of bone and collagen turnover in acromegaly or $\frac{2}{D}$ markers of bone and collagen turnover in acromegaly or \&

25 Gennari C, Imbimbo B, Montagnani M, Bernini M, Nardi P, Avioli LV. Effects of prednisone and deflazacort on $\frac{\bar{O}}{3}$ mineral metabolism and parathyroid hormone activity in humans. Calcif Tissue Intern 1984; 36: 245-52.

26 Jowell PS, Epstein S, Fallon MD, Reinhardt TA, Ismail F. 1,25 Dihydroxyvitamin D3 modulates glucocorticoid induced alteration in serum bone Gla protein and bone $O$ histomorphometry. Endocrinology 1987; 120: $531-6$.

27 Pastoureau P, Chavassieux P, Chapuy MC, Delmas PD, Meunier PJ. Glucocorticoid-induced osteoblastic depression in ewes. A biochemical and histological study. Bone Miner 1992; 17 (suppl 1): 158

28 Wong GL. Basal activities and hormone responsiveness of osteoclast-like and osteoblast-like bone cells are regulated osteoclast-like and osteoblast-like bone cells are regulated 9 by glucocorticoids. F Biol Chem 1979; 254: 6337-40. Mosekilde L. The effects of high-dose glucocorticoid $D$ administration on serum bone gamma carboxyglutamic acid-containing protein, serum alkaline phosphatase and vitamin D metabolites in normal subjects. Bone Miner 1988; N 4: $105-13$

30 Pocock NA, Eisman JA, Dunstan CR, Evans RA, Thomas N DH, Huq NL. Recovery from steroid-induced osteoporosis. N Ann Intern Med 1988; 107: 319-23. 